\title{
LAND SNAIL COMMUNITIES IN LIMESTONE GORGES FROM THE SOUTHERN PART OF THE METALIFERI MOUNTAINS (APUSENI MOUNTAINS, ROMANIA)
}

\author{
Voichiţa GHEOCA * and Lorena POPESCU ** \\ * "Lucian Blaga” University of Sibiu, Faculty of Sciences, Department of Ecology and Environment \\ Protection, Dr. Ion Rațiu Street 5-7, Sibiu, Sibiu County, Romania, RO-550012, \\ voichita.gheoca@ulbsibiu.ro \\ ** Ioan Virgil Ispas Street 13, Cisnadie, Sibiu County, Romania, RO-555300, plorena0691@gmail.com
}

DOI: 10.2478/trser-2018-0020

KEYWORDS: land snail communities, biodiversity, limestone, Metaliferi Mountains, Glodului, Cibului, Mada.

\section{ABSTRACT}

This study focuses on terrestrial gastropod communities in a karst area, where the presence of water and the limestone generates favourable environment for land snails. Three limestone gorges were analysed located in the southeast of the Metaliferi Mountains. Four different habitats in three limestone gorges were analysed - Glodului, Cibului and Mada. A total of 42 species of land snails were identified. The terrestrial gastropod communities in the area are dominated by calciphile species, such as Granaria frumentum, Truncatellina cylindrica and Alopia bielzii madensis. The differences between the analysed habitats are not pronounced enough to be reflected in the structure of the snail communities. Significant positive correlation was found between the abundance of land snails and the habitat exposure.

RÉSUMÉ: Communautés de gastéropodes terrestres des gorges calcaires dans la partie Sud des Montagnes Metaliferi (Montagnes Apuseni, Roumanie).

L'étude est axée sur les communautés de gastropodes terrestres dans une zone karstique ou la présence d'eaux et le substrat calcaire favorise les mollusques terrestres. Trois gorges calcaires ont été analysées, Glodului, Cibului et Mada et diferentes d’habitats. Un total de 42 espèces de gastéropodes terrestres a été identifié. Les communautés de gastéropodes terrestres de la zone considérée sont dominées par des espèces calciphile telles que Granaria frumentum, Truncatellina cylindrica et Alopia bielzii madensis. Les différences entre les habitats analysés ne sont pas suffisamment importantes pour se refléter dans la structure des communautés de mollusques. Une corrélation positive significative a été trouvée entre l'abondance des gastéropodes terrestres et l'exposition de l'habitat.

REZUMAT: Comunităţi de gastropode terestre din chei calcaroase din sudul Munților Metaliferi (Munții Apuseni, România).

Studiul se concentrează pe comunitățile de gastropode terestre dintr-o zonă carstică în care prezența apei şi substratul calcaros generează un mediu favorabil pentru moluştele terestre. Trei chei calcaroase au fost analizate, Cheile Glodului, Cibului și Măzii în diferite habitate. Un număr de 42 de specii de gastropode terestre au fost identificate. Comunitățile de gastropode terestre din zona analizată sunt dominate de specii calcifile precum Granaria frumentum, Truncatellina cylindrica și Alopia bielzii madensis. Diferențele dintre habitatele analizate nu sunt suficient de accentuate pentru a fi reflectate în structura comunităților de moluște. Corelație pozitivă semnificativă a fost găsită între abundența gastropodelor terestre și expoziția habitatului. 


\section{INTRODUCTION}

Water by its morphogenetic action generates the karst landscape valuable not only through its spectacularity but also through the diversity of organisms that find a favourable environment here. The diversity and complexity of habitats in karst areas is associated with a large diversity of organism (Pipan and Culver, 2007). Among the invertebrate species inhabiting these areas, land snails are one of the most representatives. The water source, calcium availability, diversity of habitats, presence of shelter, relief and vegetation (which offer shade as well as resources), are all responsible for the presence of important land snail communities, often with species developing very large populations (Kerney and Cameron, 1979; Nekola, 1999; Horsák, 2006).

The Geoagiu River, with its tributaries Cib, Glodului, and Mada (Balșa), drains the south-eastern part of the Metaliferi Mountains, a region consisting of a petrographic mosaic of conglomerates, sandstone, and marl which are associated with Jurassic limestone rocks (Cocean, 1988). There are two limestone massifs in the basin of the Geoagiu River - Pleaşa Glodului $(855 \mathrm{~m})$ in the north and Pleașa Mare $(712 \mathrm{~m})$ in the south. The tributaries of the Geoagiu have cut five key sectors. Among them, the Glodului, Cibului, and Mada gorges are the most important (Cocean, 1988). Each of these three limestone gorges are nature reserves, and are also included in ROSCI0029 Natura 2000 site (Glodului, Cibului and Mada gorges), with a total area of 735 ha.

The malacofauna of the Apuseni Mountains has been the subject of several recent publications (Bába and Sárkány-Kiss, 1998; Bába and Sárkány-Kiss, 2001; Domokos and Váncsa, 2005; Domokos and Lennert, 2007; Lengyel and Páll-Gergely, 2010) dealing mostly with their western part. These publications successfully complete the classical malacological works including information regarding the Apuseni Mountains (Bielz, 1867; Grossu, 1981, 1983, 1987; Kimakowicz, 1890).

This paper is focussed on the land snail fauna of the limestone gorges included in the Natura 2000 site Cheile Glodului, Cibului and Măzii (Glodului, Cibului and Mada gorges), area lacking recent information on terrestrial gastropod fauna and where studies of gastropod communities are absent.

\section{MATERIAL AND METHODS}

Semi-quantitative samples were taken during 2015 from three sampling areas - Mada Gorge, Glodului Gorge and Cibului Gorge. The location of the study area is represented in figure 1. In each sampling area, samples were taken from the forest, at the base of the limestone cliffs, and near the water. Four types of habitats were considered, and 12 sampling points were selected, varying in size of limestone outcrops, forestation and humidity. The location of the sampling points, habitat type and exposure is described in table 1 . Snails were collected by hand, by visual searching by two collectors for about one hour, and an additional leaf litter sample was taken. About $20 \mathrm{l}$. of leaf litter was sieved and the material was sorted and identified in the laboratory (Pokryszko and Cameron, 1995). The works of Grossu (1981, 1983, 1987) and Welter-Schultes (2012) were used for species identification. The taxonomic list follows Fauna Europaea (Bank, 2017).

The list of species was registered. The number of living individuals and fresh empty shells were used to estimate snail abundance. The community structure was assessed using the relative abundance of each species. The presence/absence of snail species was used to build a Jaccard similarity diagram of the sampling stations (single linkage method, Euclidean distance). Diversity was calculated based on the Shannon-Wiener biodiversity index. 


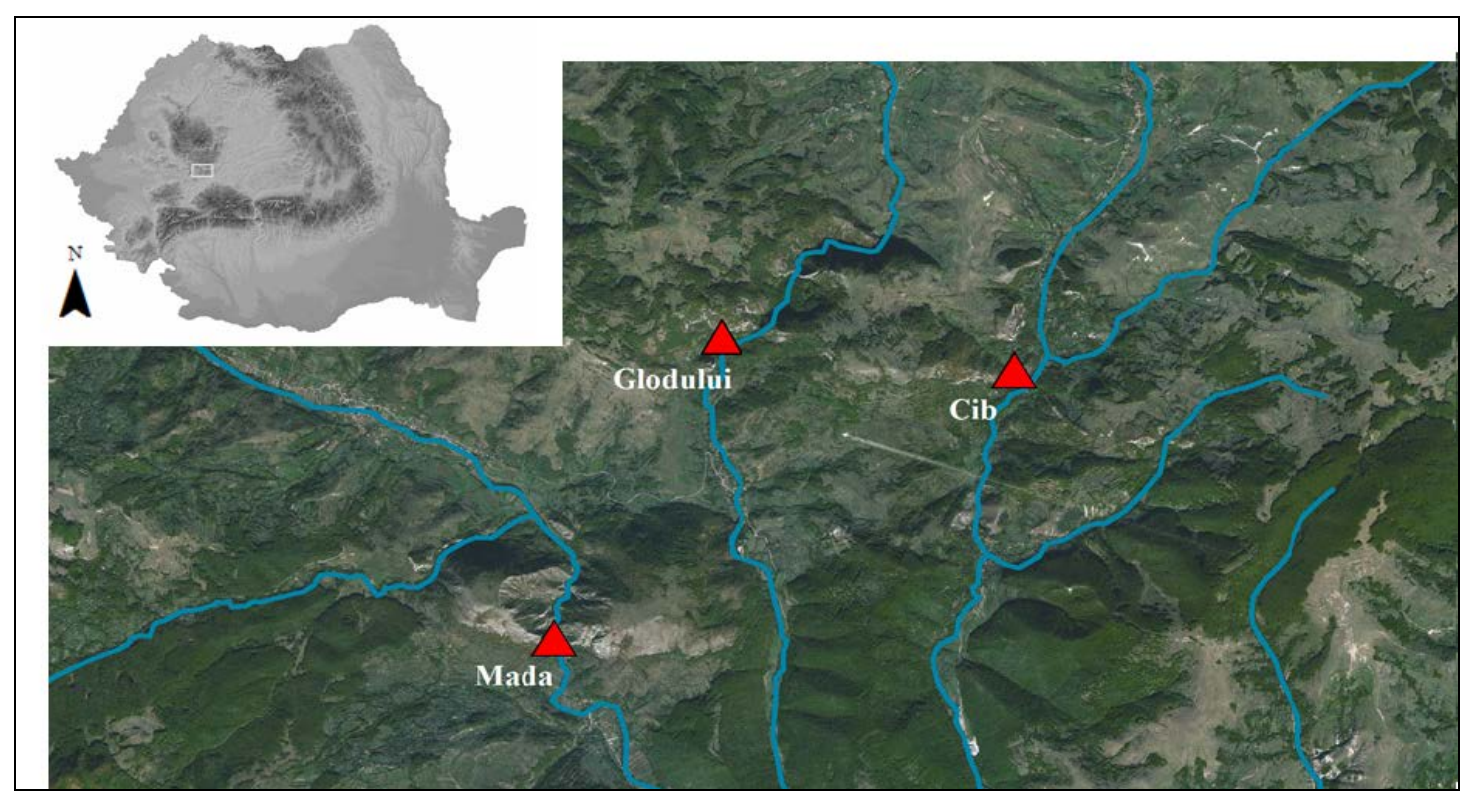

Figure 1: The location of sampling areas.

Table 1: Location and characteristics of the sampling points (G1-G4, Glodului; M1-M4, Mada; C1-C4, Cibului). The following codification was used for habitat type: 1 - limestone wall; 2 - limestone cliffs in the forest; 3 - limestone outcrops in the forest; 4 - limestone outcrops near the water.

\begin{tabular}{|c|c|c|c|c|c|c|}
\hline Sampling point & G1 & G2 & G3 & G4 & M1 & M2 \\
\hline Exposure & $\mathrm{NE}$ & $\mathrm{NE}$ & $\mathrm{NE}$ & $\mathrm{N}$ & $S$ & SV \\
\hline Habitat type & 3 & 4 & 2 & 1 & 2 & 4 \\
\hline Coordinates & $\begin{array}{l}46.0175 \mathrm{~N} \\
23.1451 \mathrm{E}\end{array}$ & $\begin{array}{l}46.0173 \mathrm{~N} \\
23.1459 \mathrm{E}\end{array}$ & $\begin{array}{l}46.0172 \mathrm{~N} \\
23.1459 \mathrm{E}\end{array}$ & $\begin{array}{l}46.0328 \mathrm{~N} \\
23.1411 \mathrm{E}\end{array}$ & $\begin{array}{l}46.0073 \mathrm{~N} \\
23.1250 \mathrm{E}\end{array}$ & $\begin{array}{l}46.0073 \mathrm{~N} \\
23.1258 \mathrm{E}\end{array}$ \\
\hline Altitude & 437 & 416 & 419 & 481 & 348 & 348 \\
\hline Sampling point & M3 & M4 & C1 & $\mathrm{C} 2$ & C3 & C4 \\
\hline Exposure & SV & SV & SE & $\mathrm{NE}$ & $E$ & $\mathrm{~N}$ \\
\hline Habitat type & 3 & 1 & 3 & 1 & 4 & 2 \\
\hline Coordinates & $\begin{array}{l}46.0074 \mathrm{~N} \\
23.1253 \mathrm{E}\end{array}$ & $\begin{array}{l}46.0075 \mathrm{~N} \\
23.1258 \mathrm{E}\end{array}$ & $\begin{array}{l}46.0363 \mathrm{~N} \\
23.1777 \mathrm{E}\end{array}$ & $\begin{array}{l}46.0363 \mathrm{~N} \\
23.1771 \mathrm{E}\end{array}$ & $\begin{array}{l}46.0319 \mathrm{~N} \\
23.1782 \mathrm{E}\end{array}$ & $\begin{array}{l}46.02178 \mathrm{~N} \\
23.1719 \mathrm{E}\end{array}$ \\
\hline Altitude & 348 & 351 & 526 & 526 & 472 & 382 \\
\hline
\end{tabular}

\section{RESULTS AND DISCUSSION}

A total of 16,303 specimens from 42 species were found in the samples. The species diversity is comparable to that found in other karst areas of Romania (Gheoca, 2016). The systematic list of encountered species is presented in table 2. Consistent with the nature of the karst habitats, most of the land snail's species present in the area are specific for dry open calcareous habitats. Twenty-eight species were found in all three gorges. The rest of the species are less common, occasionally present in some of the samples and only in small number; the exception was Pupilla triplicata, which was only found in Glodului and Mada gorges, and was very abundant in the latter. 
Table 2: Systematic list of land snail species identified in the area. The presence in the sampling areas is represented as well the zoogeographic elements, the relative abundance (A) and frequency ( $\mathrm{F}$ ) expressed as percentages (all the samples are considered). The highest values are presented in bold; Mada-M, Glodului-G, Cib-C.

\begin{tabular}{|c|c|c|c|c|}
\hline Species & Area & A\% & $\mathbf{F} \%$ & $\begin{array}{l}\text { Zoogeogarphic } \\
\text { elements }\end{array}$ \\
\hline Platyla banatica (Rossmässler 1842) & $\mathrm{C}$ & 0.006 & 8.33 & E-European \\
\hline Platyla perpusilla (Reinhardt 1880) & M, G, C & 0.035 & 66.66 & E-European \\
\hline Succinella oblonga (Draparnaud 1801) & M, G, C & 0.006 & 8.33 & Eurasian \\
\hline Cochlicopa lubricella (Rossmässler 1834) & M, G, C & 0.808 & 83.33 & European \\
\hline Sphyradium doliolum (Bruguière 1792) & M, G, C & 0.717 & 91.66 & European \\
\hline Spelaeodiscus triarius (Rossmässler 1839) & M, G, C & 0.791 & 91.66 & CE-Eurropean \\
\hline Vallonia costata (Müller O. F. 1774) & M, G, C & 4.733 & 83.33 & Palearctic \\
\hline Vallonia excentrica Sterki 1893 & M, G, C & 0.864 & 75 & Holarctic \\
\hline Acanthinula aculeata (Müller O. F. 1774) & M, G, C & 0.622 & 91.66 & W Palearctic \\
\hline Pupilla muscorum (Linnaeus, 1758) & M, G, C & 0.328 & 50 & European \\
\hline Pupilla triplicata (Studer S., 1820) & M, C & 3.580 & 58.33 & SE-Eurropean \\
\hline Pyramidula pusilla Gitt. and Bank 1996 & M, G, C & 4.952 & 91.66 & European \\
\hline Granaria frumentum (Draparnaud 1801) & M, G, C & 27.041 & 100 & CE-European \\
\hline Chondrina clienta (Westerlund 1883) & M, G, C & 5.206 & 91.66 & CE-European \\
\hline Truncatellina cylindrica (Férussac 1807) & M, G, C & 11.480 & 100 & W Palearctic \\
\hline Vertigo pusilla Müller O. F. 1774 & M, G, C & 0.048 & 50 & European \\
\hline Vertigo pygmaea (Draparnaud 1801) & $\mathrm{M}, \mathrm{C}$ & 0.011 & 16.66 & Holarctic \\
\hline Merdigera obscura (Müller O. F. 1774) & $\mathrm{M}, \mathrm{C}$ & 0.012 & 25 & W Palearctic \\
\hline Chondrula tridens (Müller O. F. 1774) & $\mathrm{M}, \mathrm{G}, \mathrm{C}$ & 2.116 & 66.66 & European \\
\hline Alopia bielzii madensis (Fuss C. 1855) & $\mathrm{M}, \mathrm{G}, \mathrm{C}$ & 8.162 & 83.33 & Endemic \\
\hline Cochlodina laminata (Montagu 1803) & M, G, C & 0.588 & 75 & European \\
\hline Cochlodina orthostoma (Menke 1828) & M, G, C & 0.201 & 50 & CE-European \\
\hline Ruthenica filograna (Rossmässler 1836) & M, G, C & 7.132 & 100 & E-European \\
\hline Clausilia dubia Schmidt A. 1856 & M, G, C & 7.211 & 100 & European \\
\hline Laciniaria plicata (Draparnaud 1801) & $\mathrm{M}, \mathrm{C}$ & 2.110 & 91.66 & CE-European \\
\hline Balea biplicata (Montagu 1803) & $\mathrm{C}$ & 0.006 & 8.33 & C-European \\
\hline Bulgarica vetusta (Rossmässler 1836) & $\mathrm{C}$ & 1.84 & 58.33 & E-European \\
\hline Cecilioides acicula (Müller O. F. 1774) & $\mathrm{C}$ & 0.006 & 8.33 & W-Palearctic \\
\hline Punctum pygmaeum (Draparnaud 1801) & $\mathrm{M}, \mathrm{C}$ & 0.435 & 58.33 & Holarctic \\
\hline Discus perspectivus (von Mühlfeld 1816) & $\mathrm{G}, \mathrm{C}$ & 0.131 & 25 & CE-European \\
\hline Vitrea diaphana (Studer S. 1820) & M, C & 0.320 & 33.33 & CE-European \\
\hline Euconulus fulvus (Müller O. F. 1774) & $\mathrm{C}$ & 0.150 & 16.66 & Holarctic \\
\hline Oxychilus glaber (Rossmässler 1835) & $\mathrm{C}$ & 0.006 & 8.33 & European \\
\hline Aegopinella minor (Stabile 1864) & M, G, C & 1.851 & 83.33 & European \\
\hline Vitrina pellucida (Müller O. F. 1774) & M, G, C & 1.318 & 66.66 & Holarctic \\
\hline Fruticicola fruticum (Müller O. F. 1774) & M, G, C & 0.113 & 25 & European \\
\hline Euomphalia strigella (Draparnaud 1801) & M, G, C & 1.223 & 83.33 & CE-European \\
\hline Lozekia transsilvanica (Westerlund 1876) & $\mathrm{M}, \mathrm{G}, \mathrm{C}$ & 2.361 & 83.33 & E-Carpathian \\
\hline Drobacia banatica (Rossmässler 1838) & $\mathrm{M}$ & 0.031 & 8.66 & Carpathian endemic \\
\hline Faustina faustina (Rossmässler 1835) & M, G, C & 1.282 & 75 & Carpathian \\
\hline Cepaea vindobonensis (Pfeiffer C. 1828) & M, G, C & 0.061 & 33.33 & CE-European \\
\hline Helix pomatia Linnaeus 1758 & M, G, C & 0.062 & 41.66 & European \\
\hline
\end{tabular}


The most abundant species for all the samples was Granaria frumentum (27.041\%) followed by Truncatellina cylindrica (11.48\%), Alopia bielzii madensis (8.126\%), Clausilia dubia (7.211\%) and Ruthenica filograna (7.132\%). Regarding the frequency values, Granaria frumentum, Ruthenica filograna and Clausilia dubia were present in all the sampling points, while Sphyradium doliolum, Spelaeodiscus triarius, Acanthinula aculeata, Pyramidula pusilla and Laciniaria plicata in 11 of 12 sampling points.

Significant differences were recorded in snail abundance for the three karst areas, with values as different as 8,811 specimens (33 species) in Mada Gorge to only 5,294 (38 species) in Cibului Gorge and 2,198 (35 species) in Glodului Gorge (Fig. 2). Although the land snail abundance was very different in the three gorges, the Shannon-Wiener biodiversity index values were high, ranging between 2.035 and 2.948. Higher species richness could imply higher Shannon-Wiener diversity, not always applied due to the presence of extremely large populations for some of the snail species in several sampling stations. The Shannon-Wiener index values are higher than those found by Stamol (1991) in forest phytocoenoses in Croatia.

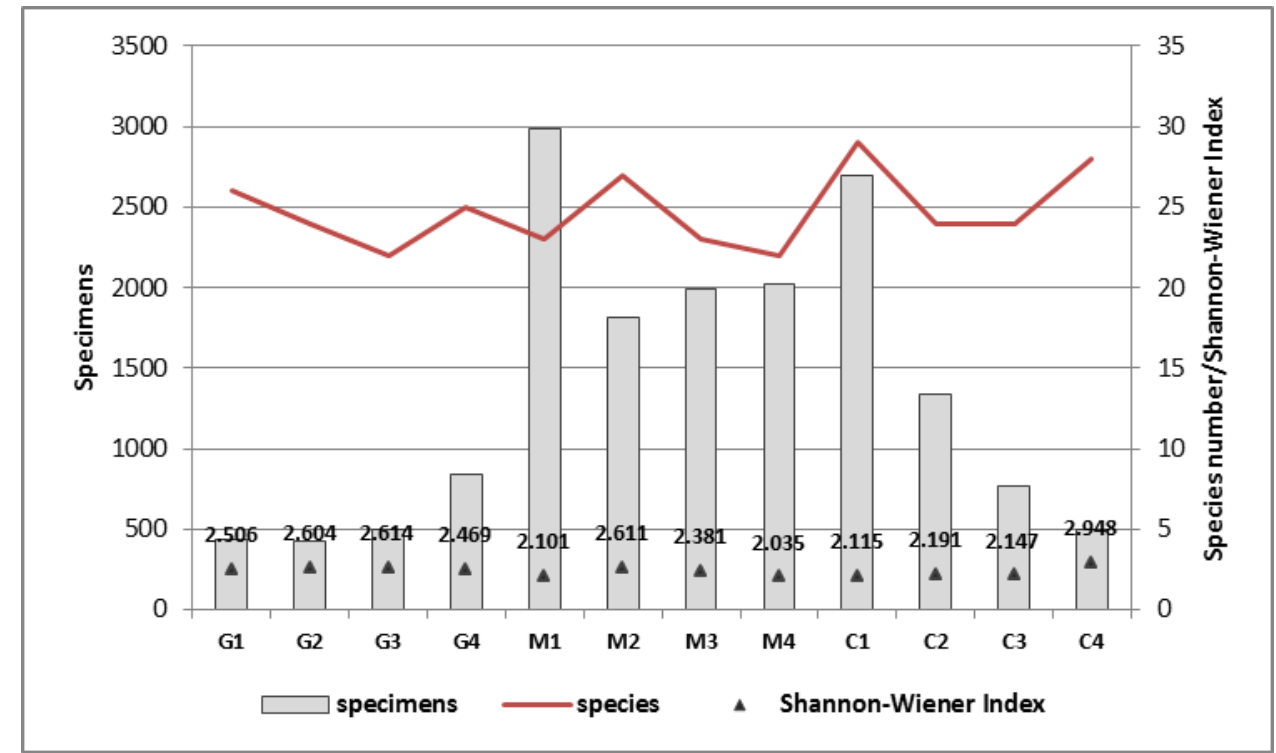

Figure 2: The number of species and specimens at each sampling point.

The differences in abundance between the three karst areas are only partly sustained by differences in community structure. The most abundant snail species in each of the three sampling areas are represented in figure 3. In Mada Gorge the land snail community is numerically dominated by microsnails such as Truncatelina cylindrica, and Vallonia costata. Granaria frumentum is also abundant, along with Clausilia dubia and Alopia bielzii madensis.

Glodului Gorge has a smaller community dominated by Granaria frumentum, Alopia bielzii madensis and Lozekia transsilvanica. G. frumentum is also the most abundant in Cibului Gorge, followed by Ruthenica filograna; the rest of the species are less abundant here.

Regarding the effect of habitat type and exposure on snail assemblages, significant positive correlation was found only between land snail abundance and exposure (Pearson $\mathrm{r}=0.8743 ; \mathrm{p}<0.001)$. 


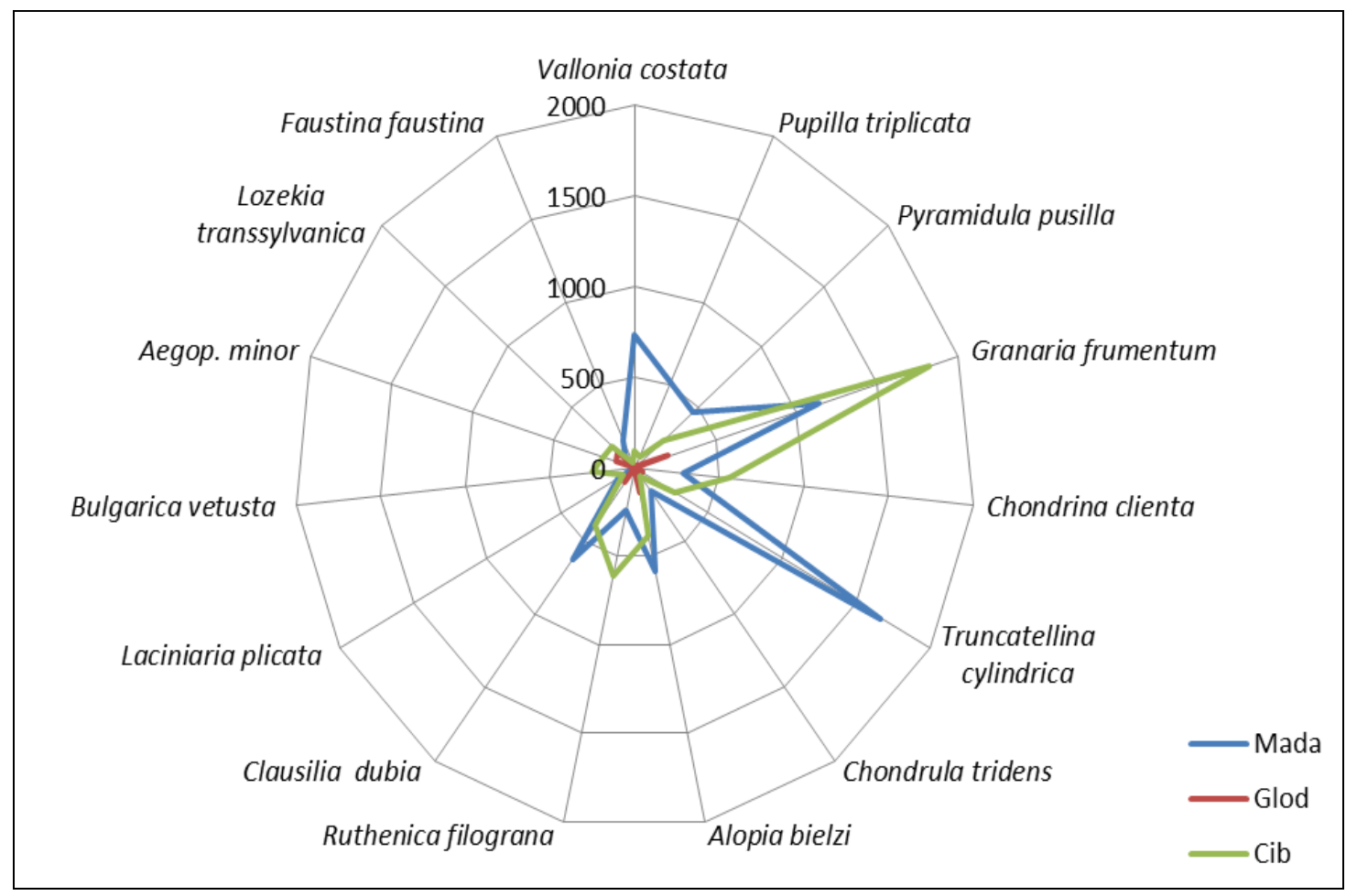

Figure 3: Abundance of the most common species in each of the three gorges.

As mentioned, the type of habitat does not significantly alter the structure of the terrestrial gastropod community. Differences between the considered habitats proved to be not so pronounced as to significantly affect the structure of the species. The habitats located near water are slightly different, where the humidity factor allows the presence of species that are not characteristic of karst habitats. Thus, species such as Drobacia banatica, Fruticicola fruticum, Euomphalia strigella, and Vitrea diaphana are only present in the areas near the water. However, their presence in small number does not significantly affect the land snail assemblage.

Exposure is the only element that seems to affect the terrestrial gastropods community, by the composition of the species, but especially by the number of individuals. This dependence, as demonstrated previously by the value of the Pearson correlation coefficient, is also reflected in the tree diagram built on the species relative abundance (Fig. 4). The tree diagram rather demonstrates a grouping after the exposure than an affinity depending on the area or type of habitat. This is due to the fact that the dominant species here, which constitute the largest part of the community in all three investigated areas, are calciphile species that are good at tolerating the high temperatures caused by direct sunlight exposure and the capacity of limestone to accumulate heat, being more abundant on the southern slopes. An example is Granaria frumentum, which represents almost a third of the land snails inhabiting the area, but also Truncatellina cylindrica and Vallonia costata.

Other species, such as Lozekia transsilvanica, Clausilia dubia, and Ruthenica filograna, become codominant only in the forested areas with a northern or western exposure. 


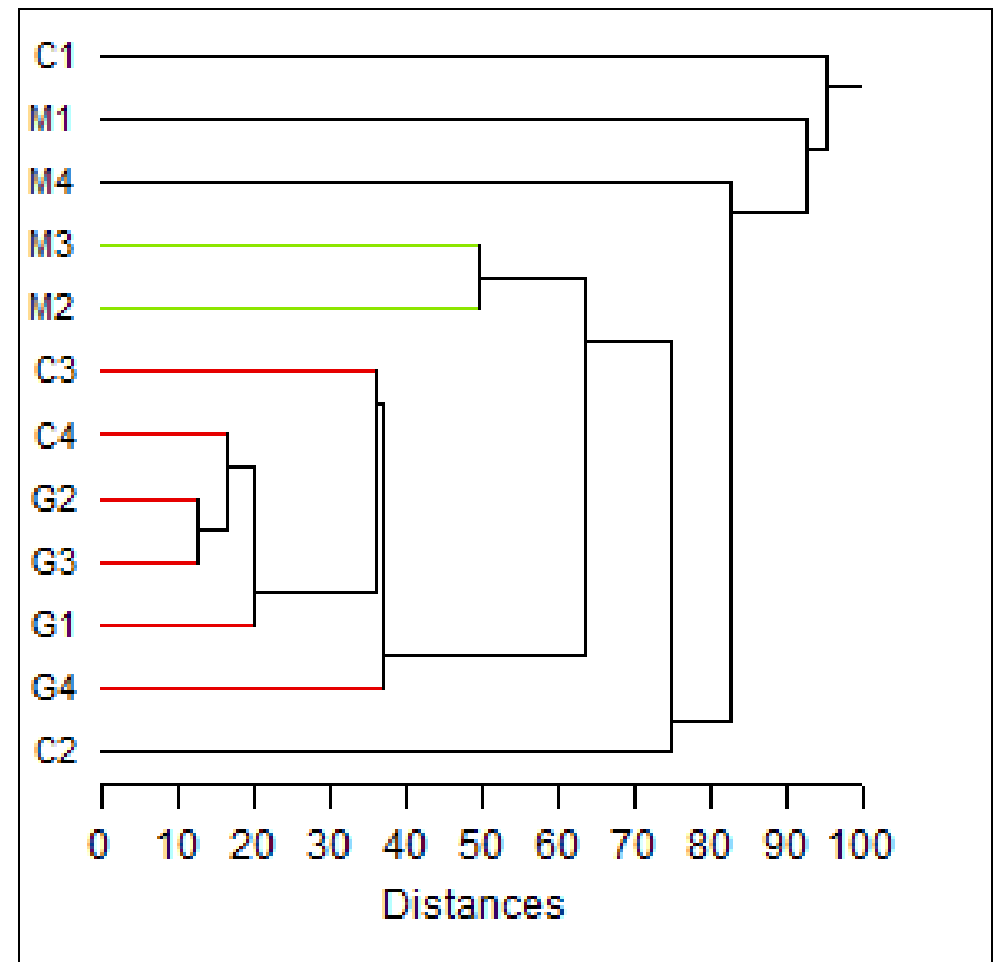

Figure 4: Cluster analysis of sampling sites based on species relative abundance (single linkage, Euclidean distance).

\section{CONCLUSIONS}

The karst area in the southwest of the Metaliferi Mountains has characteristic malacofauna, as is usually found in limestone areas, dominated by species associated with limestone habitats that sometimes develop very large populations. The three gorges are significantly different in terms of land snail abundance; the largest number of individuals was collected in Mada Gorge, followed by Cib Gorge and the lowest abundance characterized the habitats of Glodului Gorge, with about a quarter of the abundance found in Mada Gorge.

The most abundant species are Granaria frumentum, Truncatellina cylindrica, Clausilia dubia, Ruthenica filograna and the endemic calciphile species Alopia bielzii madensis. In humid habitats other species like Drobacia banatica, Fruticicola fruticum, Vitrina pellucida and Euomphalia strigella can be present but without significantly affecting the community structure.

A significant positive correlation was found between land snail abundance and exposure, the southern slopes having significantly larger populations of the calciphile species. 


\section{REFERENCES}

1. Bank R. A. (ed.), 2017 - Fauna Europaea Project - Checklist of the land and freshwater Gastropoda of Europe, https://fauna-eu.org.

2. Bába K. and Sárkány-Kiss A., 1998 - Neue Beiträge zur Kenntnis der Molluskenfauna der Tordauer Schlucht (Cheile Turzii, Rumänien), Nachrichtenblatt der Ersten Vorarlberger Malakologischen Gesellschaft, 6, 9-14. (in German)

3. Bába K. and Sárkány-Kiss E., 2001 - The malacofauna of Belavara - Scărița Belioara Mountain (Bihor Mountains, Romania), Nachrichtenblatt der Ersten Vorarlberger Malakologischen Gesellschaft, 9, 21-25.

4. Bielz E. A., 1867 - Fauna der Land und Süsswasser-Mollusken Siebenbürgens, 2, Auflage, Hermannstadt, 216. (in German)

5. Cocean P., 1988 - Chei și defilee din Munții Apuseni, Edit. Academiei, București, 1-166. (in Romanian)

6. Domokos T. and Váncsa K., 2005 - Malacofaunistical and ecological data from the Troaș Valley, Tiscia, 35, 17-26.

7. Domokos T. and Lennert J., 2007 - Standard faunistical work on the molluscs of Codru-Moma Mountains (Romania), NYMPHAEA Folia Naturae Bihariae, Oradea, 34, 67-95.

8. Gheoca V., 2016 - Land snail communities of Cheile Vârghișului Nature Reserve (the Perșani Mountains, Romania), Studia Universitatis Babeş-Bolyai Biologia, LXI, 2, 167-176.

9. Grossu A. V., 1981 - Gastropoda Romaniae 3, Ordo Stylommatophora, Suprafamiliile Clausiliacea şi Achatinacea, Edit. Litera, Bucureşti, 1-248. (in Romanian)

10. Grossu A. V., 1983 - Gastropoda Romaniae, 4, Ordo Stylommatophora, Suprafamiliile Arionacea, Zonitacea, Ariophantacea şi Helicacea, Edit. Litera, Bucureşti, 1-538. (in Romanian)

11. Grossu A. V., 1987 - Gastropoda Romaniae 2, Subclasa Pulmonata, Ordo Basommatophora şi Ordo Stylommatophora, Suprafam. Succineacea, Cochlicopacea, Pupillacea, Edit. Litera, București, 1-388. (in Romanian)

12. Horsák M., 2006 - Mollusc community patterns and species response curves along a mineral richness gradient: a case study of fens, Journal of Biogeography, 33, 98-107.

13. Kerney M. P. and Cameron R. A. D., 1979 - Field guide to the land snails of the British Isles and north-western Europe, Collins Press, London, 288.

14. Kimakowicz M., 1890 - Beitrag zur Mollusken Fauna Siebenbürgens, II, Nachtrag, Verhandlungen und Mitteilungen des Siebenbürgischen Vereins für Naturwissenschaften zu Hermannstadt, 40, 1-113. (in German)

15. Lengyel G. D. and Páll-Gergely B., 2010 - Notes on the landsnail (Gastropoda) and harvestman (Opiliones) fauna of Bihor and Vlădeasa Mountains, Studii și Comunicări Seria Științele Naturii, Satu Mare, X-XI, 91-111.

16. Nekola J. C., 1999 - Terrestrial gastropod richness of carbonate cliff and associated habitats in the Great Lakes region of North America, Malacologia, 41, 231-252.

17. Pipan T. and Culver D. C., 2007 - Epikarst communities: biodiversity hotspots and potential water tracers, Environmental Geology, 53, 265-269.

18. Pokryszko B. M. and Cameron R. A. D., 2005 - Geographical variation in the composition and richness of forest snail faunas in northern Europe, in Cameron R. A. D., Nekola J. C. Pokryszko B. M. and Wells F. E. (eds), Pattern and process in land mollusc diversity, Perth, Records of the Western Australian Museum, Supplement 6, 115-132.

19. Stamol V., 1991 - Coenological study of snails (Mollusca, Gastropoda) in forest phytocoenoses of Medvednica Mountain (NW Croatia, Yugoslavia), Vegetatio, 95, 33-54.

20. Welter-Schultes F. W., 2012 - European non-marine molluscs, a guide for species identification, Planet Poster Editions, Göttingen, 1-674. 